\title{
Kommentar
}

\section{Farlige urter?}

Legemiddeltilsetninger, tungmetaller og andre fremmedstoffer i urteprodukter - i tillegg til forveksling av urter - er et internasjonalt problem. I Norge er det avdekket flere tilfeller av legemiddeltilsetninger i urtepreparater, i tillegg til et alvorlig tilfelle der det dreide seg om forveksling av urter i et kinesisk urteprodukt.

Det kommer jevnlig advarsler fra myndighetene om skadelige produkter som markedsføres som urtebaserte kosttilskudd via ulike salgskanaler. De fleste kosttilskudd er trygge, men noen aktører tilbyr likevel helsefarlige produkter. Hurtig og kraftig virkning av et produkt kan skyldes tilsetning av legemidler. Vanlige eksempler på dette er urteprodukter som skal stimulere potensen, gi raskt vekttap eller virke ved ulike typer smerter.

Innsikt i pasientens totale forbruk av helseprodukter kan bidra til å forklare tilsynelatende uforklarlige tilstander. Øvrehus og medarbeideres kasuistikk viser at også norske pasienter blir rammet av bivirkninger forårsaket av risikoprodukter. Statens legemiddelverk advarte allerede i 2000 om faren for Aristolochia i kinesiske urtepreparater (1). I Storbritannia har legemiddelmyndighetene på bakgrunn av liknende funn laget informasjonssider til publikum om kinesisk medisin og om urteprodukter med spesiell risiko knyttet til produksjons- og omsetningskjeden (2).

Til tross for at mange bivirkninger ikke blir rapportert, er det gjort flere viktige funn som avspeiler det internasjonale risikobildet hos norske pasienter. I 2004 ble det på bakgrunn av bivirkningsmeldinger avdekket at kosttilskuddet Phu Chee inneholdt deksametason, etter at leger oppdaget alvorlige steroidbivirkninger hos flere pasienter som hadde kjøpt legemidlet via Internett i Norge og Sverige (3).

Rapportering av alvorlige leverbivirkninger etter bruk av kosttilskuddet Fortodol førte til at det i 2009 ble avdekket at råstoffet var tilsatt det levertoksiske smertestillende legemidlet nimesulid. Kosttilskuddet ble markedsført som et mildt smertestillende urteprodukt og solgt i helsekostbutikker og via Internett. Produktet skulle ifølge innholdsdeklarasjonen inneholde gurkemeie (Curcuma longa L). Analyser av ulike råvarepartier viste at 70000 av 100000 solgte bokser inneholdt nimesulid. Saken illustrerer hvordan informasjon om pasientens totale forbruk av helseprodukter er avgjørende for å kunne avdekke slike saker (3-5).

Ettersom kosttilskudd er regulert som matvarer, finnes det ikke noe eget overvåkingssystem for bivirkninger av kosttilskudd. Bivirkningsmeldingene som kommer inn til Legemiddelverket via de regionale legemiddelinformasjonssentrene (RELIS), oversendes til Mattilsynet. Mattilsynet gjennomfører i tillegg ulike analyseprosjekter i forbindelse med sine tilsyn, hvor det blant annet er funnet sildenafilanaloger i helsekostprodukter som skal bedre potensen.

Det er mangelfull kunnskap om effektene av kosttilskudd og urtemedisin. Hvordan urter virker og hva slags dokumentasjon som foreligger er viktige opplysninger for å kunne unngå risikoprodukter. Kartlegginger konkluderer med at det foreligger stort behov for mer kunnskap (6).

Helsepersonell bør melde mistenkte interaksjoner og bivirkninger av helseprodukter og legemidler til RELIS. For å avdekke mu- lige bivirkninger må pasientens totale forbruk av denne typen produkter registreres.

\section{Gro Fossum}

gro.fossum@legemiddelverket.no Statens legemiddelverk

Gro Fossum (f. 1969) er farmasøyt ved Statens legemiddelverk og medlem av arbeidsgruppen Working Party on Community monographs and Community list (MLWP), som er en undergruppe av komiteen for plantebaserte legemidler i EU (HMPC).

Ingen oppgitte interessekonflikter.

Litteratur

1. Statens legemiddelverk. Preparater i fokus 2000. Atvaring mot Aristolochia. www.slv.no/templates/ InterPage 16017.aspx (24.8.2011).

2. The Medicines and Healthcare products Regulatory Agency (MHRA) advice for consumers on using traditional chinese medicines (TCMs) www.mhra.gov.uk/Safetyinformation/index.htm (24.8.2011).

3. Statens legemiddelverk. Årsrapporter for bivirkninger. www.legemiddelverket.no/templates/ InterPage__ 16153.aspx (23.8.2011).

4. Statens legemiddelverk. Legemiddelverket advarer mot kosttilskuddet Fortodol: ny rapport viser at 7 av 9 varepartier inneholder ulovlig tilsatt legemiddel (nimesulid). www.legemiddelverket.no/ templates/InterPage__ 80736.aspx (23.8.2011).

5. Kechagias S, Hägg S, Lotfi K. Läkemedelsorsakad leverskada av kosttillskottet fortodol. Manipulerat preparat försenade diagnos. Läkartidningen 2010; 107: $186-8$

6. Dietary supplements. FDA should take further actions to improve oversight and consumer understanding. www.gao.gov/products/GAO-09-250 (23.8.2011).

Mottatt 19.8. 2011, første revisjon innsendt 26.8 2011, godkjent 31.8. 2011. Medisinsk redaktør Mette Sagsveen. 